\title{
Determination of Trace Mineral Elements in some Tropical Fruits
}

\author{
Gogo Appolus Obediah ${ }^{1}$, Kemzi Nosike Elechi-Amadi \\ ${ }^{1}$ Chemistry Department, Rivers State University of Science and Technology, Port Harcourt, Nigeria \\ ${ }^{2}$ Department of Medical Laboratory Science, Rivers State University of Science and Technology, Port Harcourt, Nigeria
}

\begin{abstract}
Trace mineral elements play a vital role in the metabolic pathways in humans, when available in adequate concentrations. These elements may be present in varying amount in fruits. This study was carried out to determine the concentration of some the trace mineral element in some tropical fruits commonly consumed in Port Harcourt metropolis in Nigeria. The mineral elements measured included: $\mathrm{Co}, \mathrm{Fe}, \mathrm{Mn}, \mathrm{Ni} \& \mathrm{Zn}$. The levels of these elements were analyzed in banana, cucumber, guava, mango, orange and tomato, using AAS after acid digestion. The results obtained were as follow Co between $0.0108-0.0156 \mathrm{mg} / \mathrm{kg}, \mathrm{Fe}$ between $0.066-0.119 \mathrm{mg} / \mathrm{kg}$, Mn between $0.0051-0.0117 \mathrm{mg} / \mathrm{kg}$, Ni between $0.002-0.012 \mathrm{mg} / \mathrm{kg}$ and $\mathrm{Zn}$ between $0.0276-0.0624$. These trace mineral elements were found in comparatively low concentration in the six tropical fruits used for this research
\end{abstract}

Keywords: tropical fruits, human nutrients, trace mineral elements, Co, Fe, Mn, Ni, Zn,

\section{Introduction}

Fruits are the ripen ovary of flowering plant. Tropical fruits require tropical climate and originate from the tropics, they includes: Banana, Cucumber, Guava, Mango, Orange and Tomato.

Fruits are a good source of essential mineral elements that are necessary for multiple physiological and metabolic reactions involved in maintaining good health [1]. They are comparatively in low amount in fruits but play an important role in human. Trace elements do not provide any calorie but they play an important role in the metabolic regulation of the human body. Increased fruit consumption can improve mineral regulation and reduce cardiovascular diseases and certain cancer risks [2].

Trace mineral consistency of fruits depends on different factors e.g. genetic, weather, soil, the harvesting stage of maturity and their supply to the market. Mineral content reduced in plants by the climatic conditions due to rain, mist, fog, light and temperature and then further loss takes place due to less suitable storage conditions. If the cultivated soil is deficient in certain trace mineral element then the cultivated crop would ultimately be deficient for those mineral. Trace minerals help the body maintain body $\mathrm{pH}$, osmotic regularity and acts as coenzyme which regulates metabolic reactions.

Cobalt (Co): Co is an indispensible element; it is an integral component of cyanocobalamin (vitamin $\mathrm{B}_{12}$ ). It is essential for the formation of red blood cell and maintenance of nerve tissue. Co deficiency plays a role in producing anoxia and injuring the heart muscle [3]. The daily recommended range of Co in human diet is $0.005 \mathrm{mg} /$ day [4]. Co intake greater than 30mg/day can cause digestive and skin disorders in human.

Iron (Fe): Fe is a core component of the red blood cells. Its deficiency can cause anemia. Fe is needed in the formation of hemoglobin and myoglobin. The daily intake limit is 8-
$11 \mathrm{mg} /$ day [5].

Manganese (Mn): $\mathrm{Mn}$ is one of the important essential elements required for carbohydrates metabolism as well as an antioxidant in superoxide dimutases enzymes. It is required in very little quantity and its deficiency rarely occur. The daily intake is $1.8-2.3 \mathrm{mg} /$ day [5].

Nickel (Ni): Ni plays its role as a coenzyme in different enzymes. Lower content of $\mathrm{Ni}$ in fruits and vegetables source can lead to increase blood sugar level, hypertension and deficient growth in human but on the other hand the increased uptake of $\mathrm{Ni}$ in fruits and vegetable can reduced the blood glucose level, difficulty in breathing, nausea etc. the daily intake is $3-7 \mathrm{mg} /$ day [6].

Zinc (Zn): Zn is reported as coenzyme for over 200 enzymes involved in immunity, new cell growth, acid-base regulation, etc. On the other hand, lack of sufficient amount of $\mathrm{Zn}$ results in reduced activity of related enzymes. According to study, the daily intake limit is up to $15 \mathrm{mg} /$ day [7]. While higher uptake of Zn may lead to muscle cramps, kidney damage and digestive problems. The reported limit of $\mathrm{Zn}$ for human uptake is up to $150 \mathrm{ppm}$.

Evaluation of micronutrients and essential trace elements levels of fruits and vegetables is a growing trend in nutritional studies throughout the world but limited information is available on this in this part of the world. This is what necessitated this research work.

My aim was to determine the trace element content of these tropical fruits.

\section{Materials and Methods}

\section{Minerals Determination:}

Fresh samples of fruits were air dried for seven days and then oven dried at $45^{\circ} \mathrm{C}$ to constant weight. They were grounded with porcelain mortar and pistol to fine particle size and 


\section{International Journal of Science and Research (IJSR) \\ ISSN (Online): 2319-7064 \\ Index Copernicus Value (2013): 6.14 $\mid$ Impact Factor (2015): 6.391}

stored in plastic containers for Atomic Absorption Spectrophotometer analysis. In mineral determination, these $\mathrm{Co}, \mathrm{Fe}, \mathrm{Mn}$, Ni and $\mathrm{Zn}$ were determined by atomic absorption spectrophotometer by wet digestion.

\section{Wet Digestion:}

$1 \mathrm{~g}$ of dried sample was added to $5 \mathrm{ml}$ conc. $\mathrm{HNO}_{3}$ and placed on hot plate for $1 \mathrm{hr}$ and on getting semi dried, another $5 \mathrm{ml}$ of $\mathrm{HNO}_{3}$ and $2 \mathrm{ml}$ of $\mathrm{H}_{2} \mathrm{O}_{2}$ was added and kept on hot plate for another $1 \mathrm{hr}$ and after getting semi dried, it was cooled and filtered with the help of watt man filter paper and the volume of the residue was made up to $10 \mathrm{ml}$ with $2{\mathrm{~N} \mathrm{HNO}_{3}}$ and taken for AAS analysis. This above mentioned mineral analysis was developed following AOAC standard [8].

\section{Results}

Table 1: Trace mineral element composition of some tropical fruits.

\begin{tabular}{|c|c|c|c|c|c|}
\hline & Co & $\mathbf{F e}$ & Mn & $\mathrm{Ni}$ & Zn \\
\hline & \multicolumn{5}{|c|}{$. \mathrm{mg} / \mathrm{kg} \ldots \ldots \ldots \ldots \ldots \ldots \ldots$} \\
\hline Banana & 0.0108 & 0.119 & 0.0111 & 0.006 & 0.0504 \\
\hline Cucumber & 0.0121 & 0.087 & 0.0117 & 0.012 & 0.0624 \\
\hline Guava & 0.0118 & 0.096 & 0.0109 & 0.004 & 0.0384 \\
\hline Mango & 0.0156 & 0.101 & 0.0051 & 0.006 & 0.0384 \\
\hline Orange & 0.0105 & 0.087 & 0.0072 & 0.002 & 0.0276 \\
\hline Tomato & 0.0135 & 0.066 & 0.0095 & 0.004 & 0.0392 \\
\hline
\end{tabular}

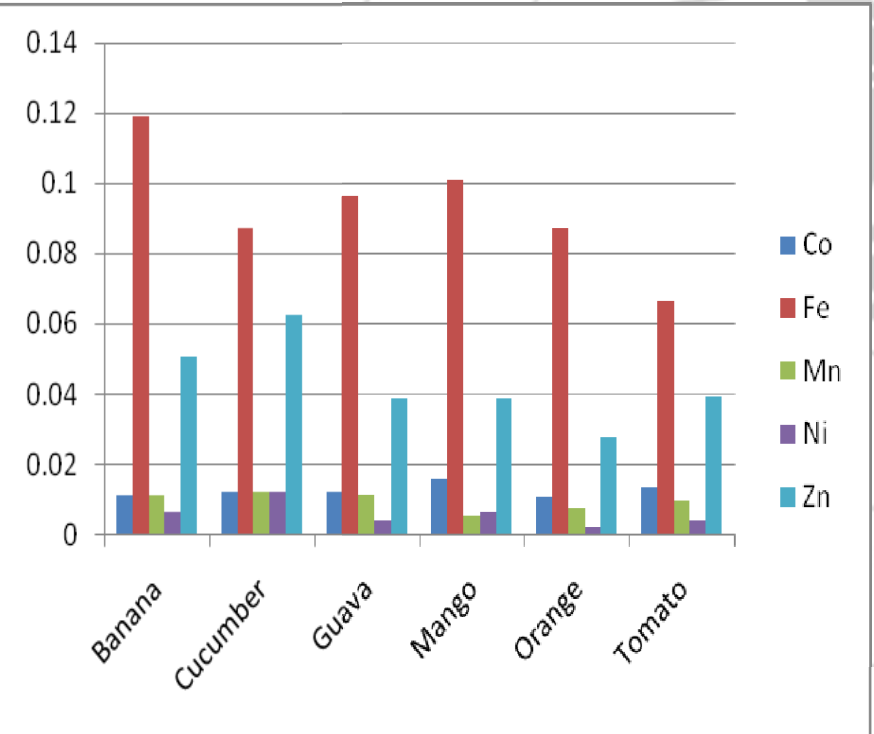

Figure 1: Trace mineral element composition of some tropical fruits.

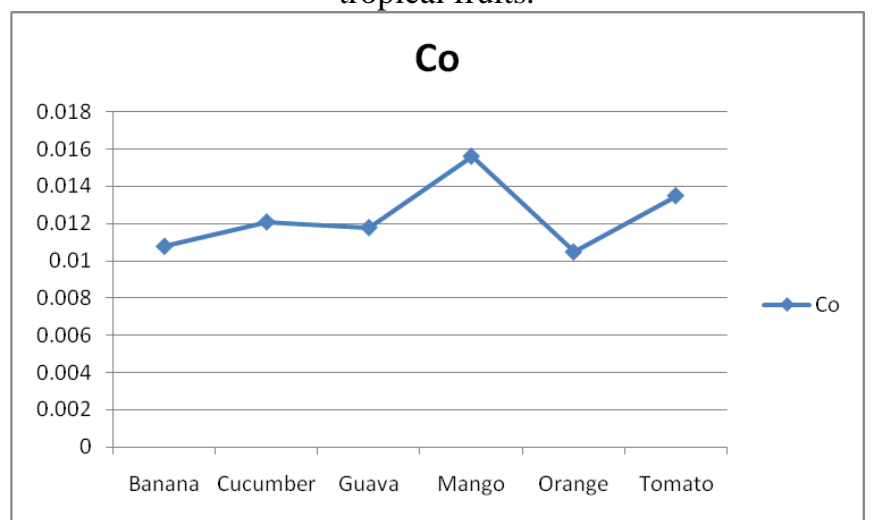

Figure 2: Cobalt (Co) composition of some tropical fruits.

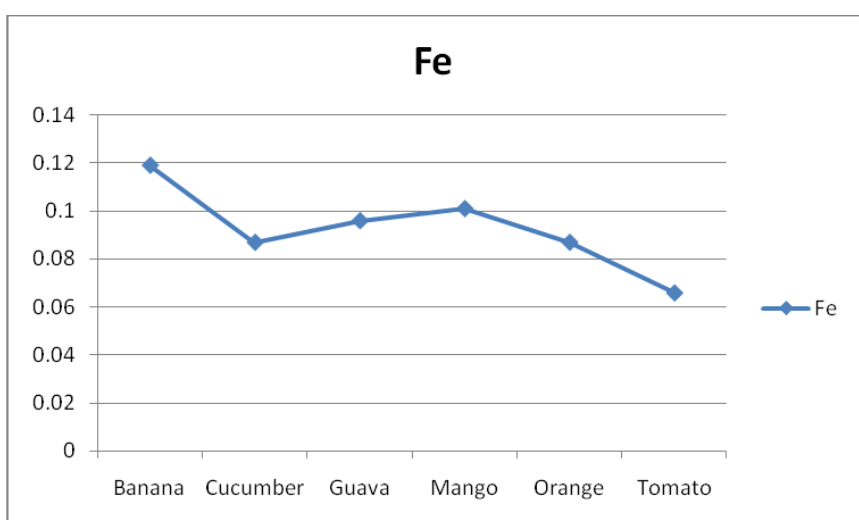

Figure 3: Iron (Fe) composition of some tropical fruits.

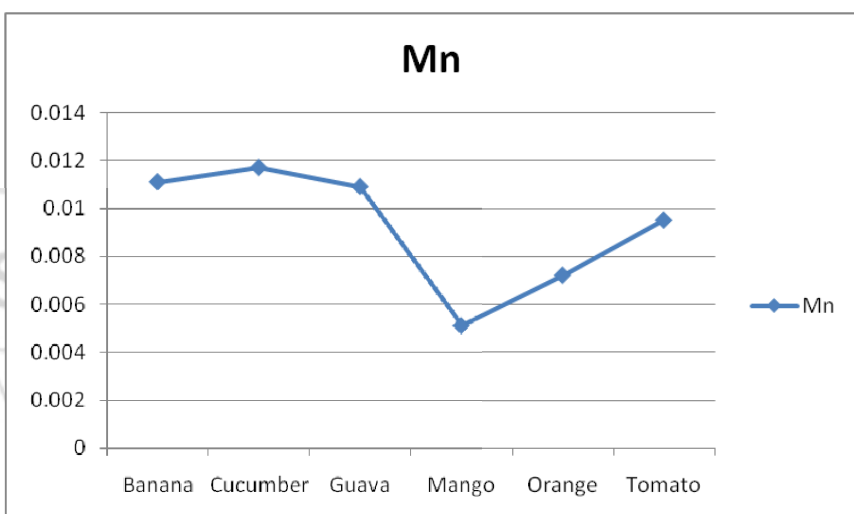

Figure 4: Manganese (Mn) composition of some tropical fruits.

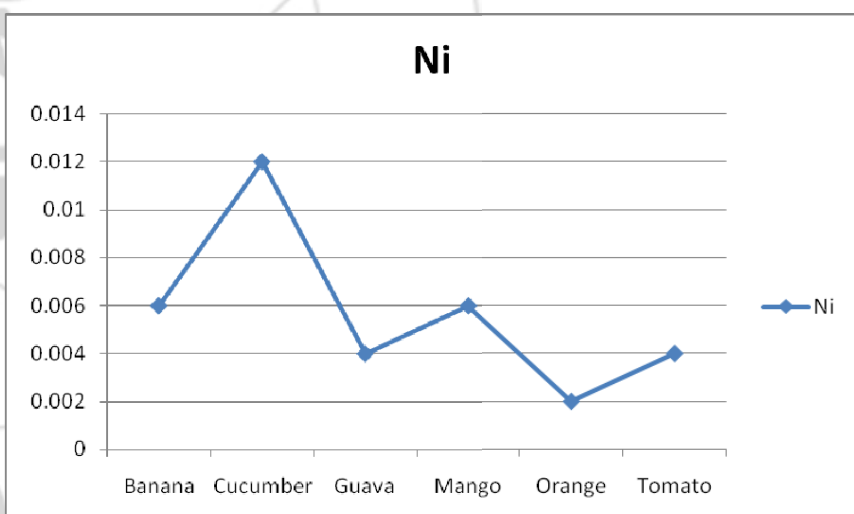

Figure 5: Nickel (Ni) composition of some tropical fruits.

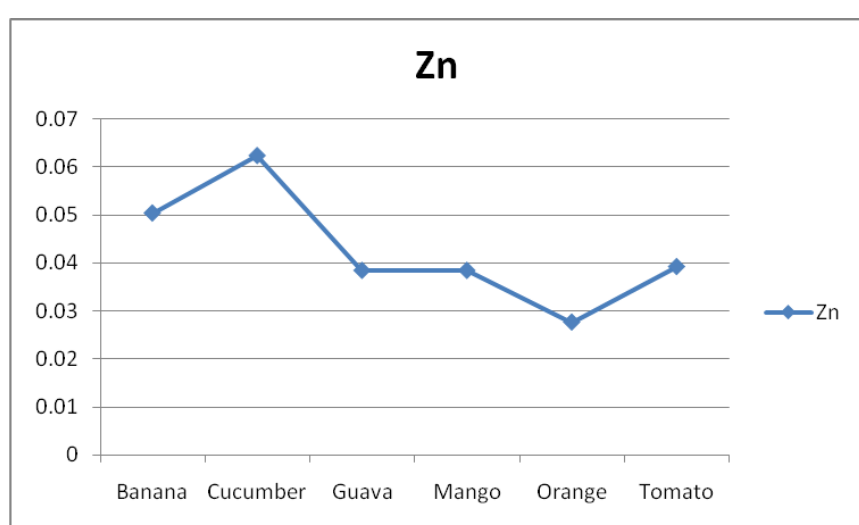

Figure 6: Zinc (Zn) composition of some tropical fruits. 


\section{International Journal of Science and Research (IJSR) \\ ISSN (Online): 2319-7064 \\ Index Copernicus Value (2013): 6.14 | Impact Factor (2015): 6.391}

\section{Discussions}

Trace elements uptakes in fruits result from absorption from the soil of the cultivated area, the atmospheric condition and partly from the irrigated water.

From the results obtained, Co was found higher in mango than other fruits. Orange contains the least concentration of Co (table 1and figure 2). Cobalt determination in fruits was shown slightly high in all fruit. According to a study carried out on Co in different food, Co variation in fruits and vegetables is $0.006-0.009 \mathrm{mg} / \mathrm{kg}$ [9].

Fe was found to be higher in banana and lesser in tomato than in other fruits (table 1 \& figure3). Fe is one of the essential metals needed in various enzymatic reactions and its daily requirement is between $1.5-2.2 \mathrm{mg} /$ day [5].

Mango contains the least concentration while cucumber contains the highest concentration of $\mathrm{Mn}$ than other fruits (figure 4). Manganese safe limit for daily intake is 2.0$5.0 \mathrm{mg} /$ day for an adult [10] and its recommended range in fruits and vegetables are $0.42-6.64 \mathrm{mg} / \mathrm{kg}[11]$

$\mathrm{Ni}$ was found higher in cucumber and lesser in orange (figure 5). Nickel is one of the toxic metal required for metabolic reactions in the body. The reported safety range is between 3$7 \mathrm{mg} / \mathrm{kg}$ [12].

Zn uptake was $0.0624 \mathrm{mg} / \mathrm{kg}$ and $0.0276 \mathrm{mg} / \mathrm{kg}$ as highest uptake in cucumber and lowest in orange (table 1 \& figure 6). Dietary intake of $\mathrm{Zn}$ is between 14-20mg/day [13].

According to this study, trace mineral elements were found in comparatively in low concentration in the six tropical fruits used for this research. This imply that there is need for consumption of large quantity of these fruits to be able to meet the daily dietary intake level.

\section{Conclusion}

Many international and national health agencies are working throughout the world to develop new standards, but in developing country like Nigeria, it is still lacking in maintaining a standard composition. According to this study, trace mineral elements were found in comparatively low concentration in the six tropical fruits used for this research.

\section{References}

[1] Goldman, I. L., A. A. Kader and C. Heintz, 1999. Influence production, handling and storage on phytonutrient content of foods. Nutr Rev., 57:S46-S52.

[2] F. Ismail, M. R. Anjum, A. N. Mamon and T. G. Kazi, 2011. Trace metal contents of vegetables and fruits of Hyderabad Retail Market. Pakistan Journal of Nutrition, 10 (4): 365-372

[3] Carson, B. L., H. V. Ellis and J. L. McCann, 1986. Toxicology and Biological Monitoring of Metals in Humans. Lewis Publishers Inc. Michigan, USA
[4] Agency for Toxic Substance and Disease Registry, 2004. Toxicological Profile of Cobalt. Us Department of Health and Human Services.

[5] Institute of Medicine, 2001. Standing committee on the scientific evaluation of dietary reference intake for vitamin A, vitamin $\mathrm{K}$, boron, chromium, copper, iodine, manganese, molybdenum, nickel, silicon, vanadium, and zinc. Washington, DC., National Academies Press, P:128

[6] Agency for Toxic Substances and Disease Registry (ATSDR), 1999. Toxicological profile for Cadmium and Nickel. Agency for Toxic Substances and Disease Registry, US Department of Health and Human Services, Public Health Service Contact No; 205-93-0606

[7] Agency for Toxic Substances and Disease Registry (ATSDR), 1994. Toxicological profile for Zinc and Cobalt. US Department of Health and Human Services, Public Health Service Contact No; 205-88-0608

[8] AOAC, 1990. Official method of analysis. $15^{\text {th }}$ Ed. Washington, DC.

[9] Leblanc, J. C., P. Verger, T. Guerin and J. L. Volatier, 2004. Etude de la'alimentation totale française, Mycotoxines, minèraux etèlement traces. In: INRADGAL (Ed.), pp:68

[10] Belitz, Grosch and Schieberle, 2007. Food Chemistry $3^{\text {rd }}$ edition, Springer-Verlage, Berlin Heidelberg. P: 793.

[11] NRC, 1989. Recommended Dietary allowances, $10^{\text {th }}$ Ed., Washington, DC., National Research Council, pp: 231235

[12] Iyaka, Y. A., U. I. Nda-Umar, M. N. Muhammed and A. I. Ajai, 2005. Contents of lead and copper in some foodstuffs commonly available in Niger State. Polymath J., 6:107-111

[13]FAO, 1973. Nutritional Meeting Report Series; TRS = WHO Technical Report Series. 